\title{
Biodeterioration of Antarctic fossil penguin bones caused by lichens from the Eocene La Meseta Formation
}

\author{
Renato García ${ }^{1}\left[\right.$ Carolina Acosta Hospitaleche ${ }^{2}\left[\right.$ - Gonzalo Márquez ${ }^{3}(\mathbb{0}$
}

Received: 1 July 2021 / Revised: 4 October 2021 / Accepted: 5 October 2021

(c) The Author(s), under exclusive licence to Springer-Verlag GmbH Germany, part of Springer Nature 2021

\begin{abstract}
A large part of the Antarctic surface is covered by lichens since they can withstand extreme environmental conditions. Lichens are primary colonizers and contribute to soil formation by deteriorating rocks through a combination of chemical and physical mechanisms. Therefore, fossil remains found exposed on the surface are usually colonized by epilithic and endolithic lichens. The objective of this work is to determine the biodeterioration generated by lichens on fossil remains and its taphonomic implications. We identified the presence of the euendolithic lichens Lecidea andersonii and Athallia holocarpa growing into fossil penguin bones from Antarctica. The bioerosive damage was evaluated using light and electron microscopic techniques. Pits corresponding to apothecium and sinuous thin fissures remodeled, or in some cases produced, by hyphae were distinguished from the cracks originating from physical weathering. The maximum depth that hyphae extend inside the bone, probably constrained by the light supply, was established to be $2.5 \mathrm{~mm}$. We provided a tool for the reconstruction of the chronology of the taphonomic events, describing the type and magnitude of the damage into the bones.
\end{abstract}

Keywords Taphonomy $\cdot$ Weathering $\cdot$ Traces $\cdot$ Fossil penguins $\cdot$ Bones $\cdot$ Endolithic

\section{Introduction}

Lichens are active agents in stone deterioration through a combination of chemical and physical mechanisms. Some lichens only inhabit natural fissures and cavities within the rocks, and their impact is predominantly mechanical (Krumbein 1969; Sterflinger and Krumbein 1997).

Renato García

ragarcia@undav.edu.ar

Carolina Acosta Hospitaleche

acostacaro@fcnym.unlp.edu.ar

Gonzalo Márquez

cosme@fcnym.unlp.edu.ar

1 Laboratorio de Biodiversidad y Genética Ambiental, Universidad Nacional de Avellaneda, CONICET, Mario Bravo 1460, Piñeyro (1870), Buenos Aires, Argentina

2 División Paleontología de Vertebrados, Museo de La Plata, Facultad de Ciencias Naturales y Museo, Universidad Nacional de La Plata, CONICET, Paseo del Bosque $s / n^{\circ}$, B1900FWA La Plata, Argentina

3 Cátedra de Palinología, Facultad de Ciencias Naturales y Museo, Universidad Nacional de La Plata, CONICET, Paseo del bosque s/n, 1900 La Plata, Argentina
Lichens not only promote rocks and fossil material weathering, but also contribute to the dissolution of minerals through the excretion of organic acids and ligands, as carbonic acid forms as a result of respiration, among others (Syers and Iskandar 1973; Barker and Banfield 1996). The calcium oxalate secreted by the mycobiont, the fungus part of the lichen, is formed in the thallus-substratum interface and is closely related to the rock in its chemical composition (Syers and Iskandar 1973; Seaward and Giacobini 1988; Edwards et al. 1991, 1992, 1994a, b; Seaward 1997; Bjelland et al. 2002). These oxalates are extremely soluble in water and act as a chelator of metal ions (Jones et al. 1980). In this sense, secondary metabolites were observed within the weathering rind below epilithic lichens (Bjelland et al. 2002), and they probably act as strong chelating agents (Syers and Iskandar 1973).

Both epilithic and endolithic lichens can mechanically and chemically damage the inner and surface of rock and bone. Although the precise mechanism for each species is still unknown, this is mostly through adhesion, penetration, and changes of volume owing to hydration-dehydration processes of the organic material, in this case the hyphal structures, and the release of metabolites having acidic and/ or chelating functions (Ascaso et al. 2002; De los Ríos and 
Ascaso 2005). They can also facilitate the installation of other microorganisms, which can contribute to the deterioration of the substrate (Bjelland et al. 2011; De los Ríos et al. 2012; Khomutovska et al. 2021). Endolithic growth is often interpreted as an adaptation to extreme and hostile environments, such as the cold deserts of Antarctica, and other hot deserts (Lange et al. 1970; Kappen et al. 1981; Friedmann 1982; Friedman and Ocampo-Friedmann 1984; Wessels and Kappen 1994). However, in other less hostile and temperate regions, endolithic lichens also occur (Tretiach and Geletti 1997). Some species are partially epilithic and partially endolithic, whereas others act as epilithic or endolithic according to the phase in their life cycle (Golubic et al. 1981). Another factor to consider is the distribution of the lichen thallus in the fissures and cracks, which is not only determined by the external environmental conditions, but also by the variation of factors on a small spatial scale such as the physicochemical features of the rock (Matthes et al. 2001; De los Ríos et al. 2005).

Endolithic growth is subdivided into subforms as chasmo-, crypto-, and euendolithic depending on the space the hyphae occupy (Golubic et al. 1981). Chasmolithic lichens grow hidden between mineral grains on the rock surface. Cryptoendolithic thalli need preexisting cavities inside the rock substratum to colonize and rarely reach the surface. These forms were first described from the Antarctica (Kappen et al. 1981; Friedmann 1982; Friedmann and OcampoFriedmann 1984) and later recognized in hot arid deserts (Lange et al. 1970; Wessels and Kappen 1994). Finally, the only forms that actively dissolve and penetrate rocks are the euendolithic lichens, in which the substratum is integrated as part of their thalli. Whereas crypto- and chasmoendolithic lichens grow in a variety of rock types including sandstones and granites, it was suggested that euendolithic growth only in calcitic substrates (Bachmann 1890, 1892, 1913, 1919; Fry 1922, 1927; Doppelbaur 1959). However, it has been reported that some endolithic lichens may have their chasmo- and euendolithic phases at different states of colonization (Ascaso et al. 1995).

There is considerable interest in saxicolous lichens and other organisms living or growing on or among rocks because they play an important role as biological weathering agents on both natural outcrops and the cultural heritage (Nimis et al. 1992; Piervittori et al. 1994, 1996, 1998; Adamo and Violante 1991; Ascaso et al. 2002; De los Ríos et al. 2009; Gazzano et al. 2009; Seaward 2015; Magnin et al. 2017). However, reports of endolithic lichens over and within bones are restricted to a few contributions (Acosta Hospitaleche et al. 2011; Gouiric-Cavalli et al. 2018; García et al. 2020), in which only the superficial aspect of the bones was evaluated.

We described the taphonomic attributes observed in both surface and cross sections of fossil bones severely attacked by endolithic lichens, identifying the areas inside the bones reached by the hyphaes using energy-dispersive $\mathrm{X}$-ray spectroscopy (EDAX). A description and interpretation of the subaerial weathering and bioerosive damage caused by lichens within the fossils is presented.

\section{Materials and methods}

\section{Materials}

Fossils MLP 08-XI-30-3/12A, MLP 08-XI-30-3/12B, and MLP 12-I-20-34 included in the present study were collected during austral summer season field trips to Marambio/Seymour Island organized by the Instituto Antártico Argentino. These materials are permanently housed in the División Paleontología Vertebrados of the Museo de La Plata (MLP), La Plata City (Argentina).

\section{Methods}

For the identification of lichens, freehand apothecia sections were used, which were observed under an optical microscope, and spot tests were performed. Keys from Øvstedal and Smith (2001) and Olech (2004) were used to taxonomically identify the lichen species.

A binocular microscope was used for the first examination of the materials. Based on the severe bioerosive attack, three penguin bones were selected for the present analysis. The weathering stage was established according to Behrensmeyer (1978), and the main taphonomic attributes were described.

The fossil with the highest density of lichens, specimen MLP 12-I-20-34, was immersed in hydrogen peroxide $\left(\mathrm{H}_{2} \mathrm{O}_{2}\right)$ for cleaning, and the organic matter was carefully removed with cotton. Transversal sections were made with a Dremel Multi-Tool Mini with a diamond cutting wheel to observe the inner layers of the fossil bone.

Scanning electron microscopy (SEM) observations were made using an FEI ESEM Quanta 200 with electron source from a tungsten filament, with accelerating voltage of $200 \mathrm{~V}$ to $30 \mathrm{kV}$, at the Departamento de Mecánica, LIMF service from the Facultad de Ingeniería (Universidad Nacional de La Plata). Samples without metalization were analyzed in low-vacuum (LoVac) mode with precision of 0.1-1 Torr. Electron probe microanalysis (energy-dispersive $\mathrm{X}$-ray spectrometry, EDAX SDD Apollo 40) enabled the recognition of the areas of the fossil reached by hyphae through the detection of light elements from boron, resolution $<135 \mathrm{eV}$, with a qualitative, semi-quantitative, and quantitative analysis capacity, and patterns for chemical element microanalyses in a sample of $1 \mathrm{~mm}^{3}$. Backscattered electron detection was used to recognize variations in the atomic number of the 
elements that appear in the samples (for example, Galván Josa et al. 2013). The grayscale expresses different elements and helps to detect the presence of hyphae expanded within the fossil.

\section{Provenance}

The samples were collected from Eocene levels of the Seymour/Marambio Island, east of the Antarctic Peninsula, West Antarctica (Fig. 1). MLP 08-XI-30-3/12A and MLP 08-XI-30-3/12B correspond to pedal phalanges of fossil penguins collected in the Submeseta II Allomember (Bartonian) of the Submeseta Formation, at locality DPV 13/84. The third specimen, MLP 12-I-20-34 corresponds to a fossil penguin coracoid collected in the Submeseta III Allomember (Priabonian) of the Submeseta Formation, at locality DPV $16 / 84$

\section{Results}

\section{Lichen identification}

Two species of lichens were found in the analyzed fossil remains, Lecidea andersonii Filson 1947 and Athailia holocarpa (Hoffm.) Arup, Frödén and Søchting 2013. Both species present an endolithic thallus, although they also show some epilitic sections around the apothecia. Both species have been previously reported in the Antarctic Peninsula; $L$. andersonii has a bipolar distribution, and A. holocarpa is cosmopolitan.

\section{External macroscopic taphonomic observations}

MLP 12-I-20-34 (Figs. 2a, 3a) and MLP 08-XI-30-3/12B (Fig. 5a) exhibit the same deterioration degree, corresponding to stage 1 of Behrensmeyer (1978), whereas MLP 08-XI30-3/12A (Fig. 6a) corresponds to stage 2 by the damage to the periosteal bone at the proximal end. As occurs in fossils preserved in desert environments, the temperature and humidity fluctuations of the Antarctica causes the lower surface of the bone (in contact with the soil or partially buried) to weather more slowly than the exposed surface.

The surface of MLP 08-XI-30-3/12B and MLP 12-I-2034 is still covered by periosteal bone and thin longitudinal fissures parallel to the fiber structure. Small and compact bones such as the phalanges MLP 08-XI-30-3/12A and MLP 08-XI-30-3/12B better withstand the deterioration produced by weathering and, consequently, these bone are destroyed more slowly than long bones. However, the proximal end of MLP 08-XI-30-3/12A is highly damaged and the trabecular bone is already exposed. Besides, diagenetic fractures are observed in the coracoid MLP 12-I-20-34, which also presents deeper cracks with an associated loss of periosteal bone.

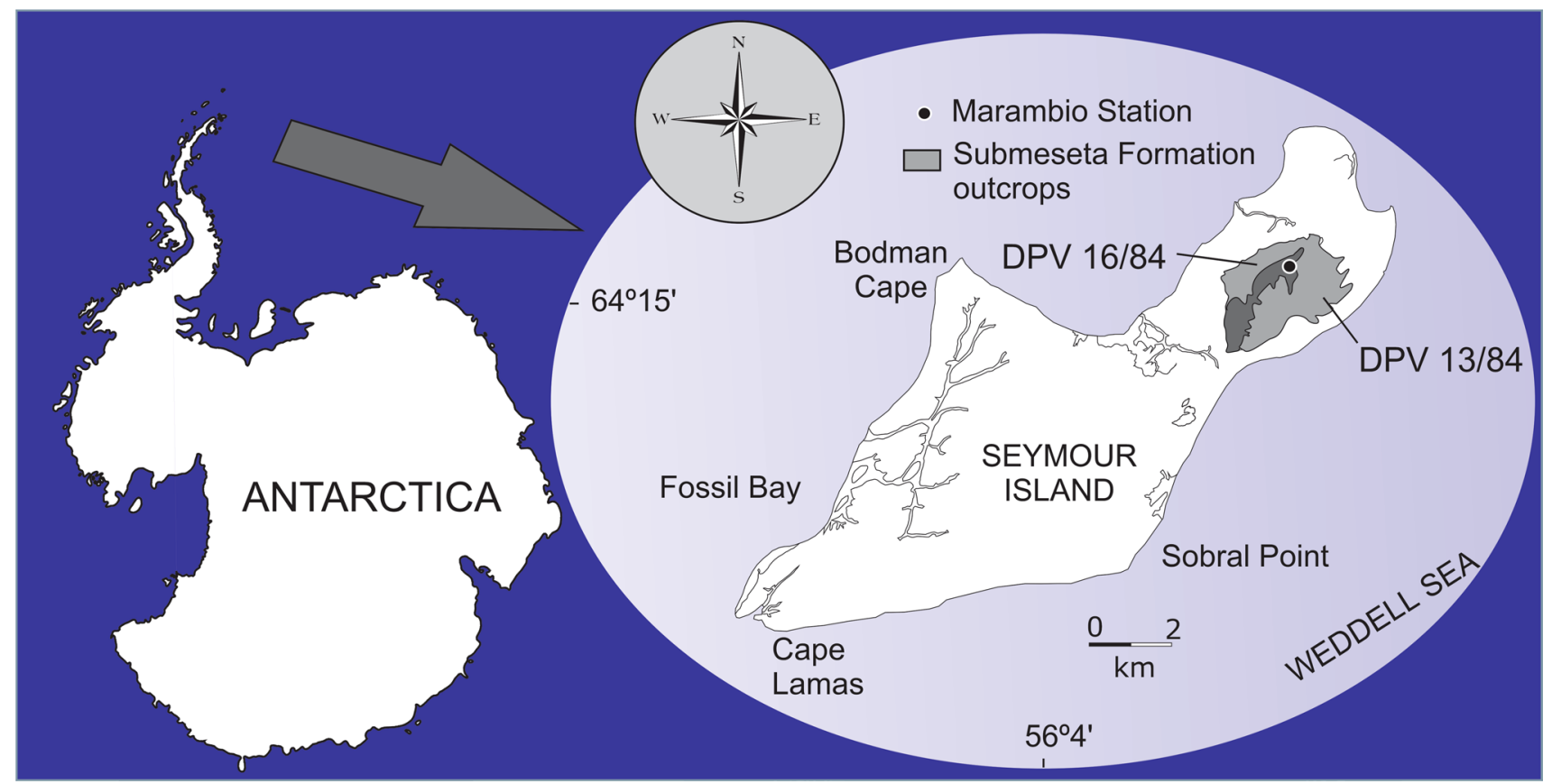

Fig. 1 Location map showing the collection sites in Seymour/Marambio Island, Antarctic Peninsula (West Antarctica) (modified from Montes et al. 2013) 
Fig. 2 Fossil specimen MLP 12-I-20-34 a Surface of the fossil before cleaning. Arrows mark apothecia and thallus of $L$. andersonii. b Surface of the fossil before cleaning. Arrows mark the traces left by the removed apothecia and thallus shown in a. c, $\mathbf{d}$ Fissures and perforations generated by lichens. The photographs were taken with a stereomicroscope. Scale bar: $1 \mathrm{~mm}$. White arrow: apothecia; black arrows: apothecium pit; white arrowheads: cracks
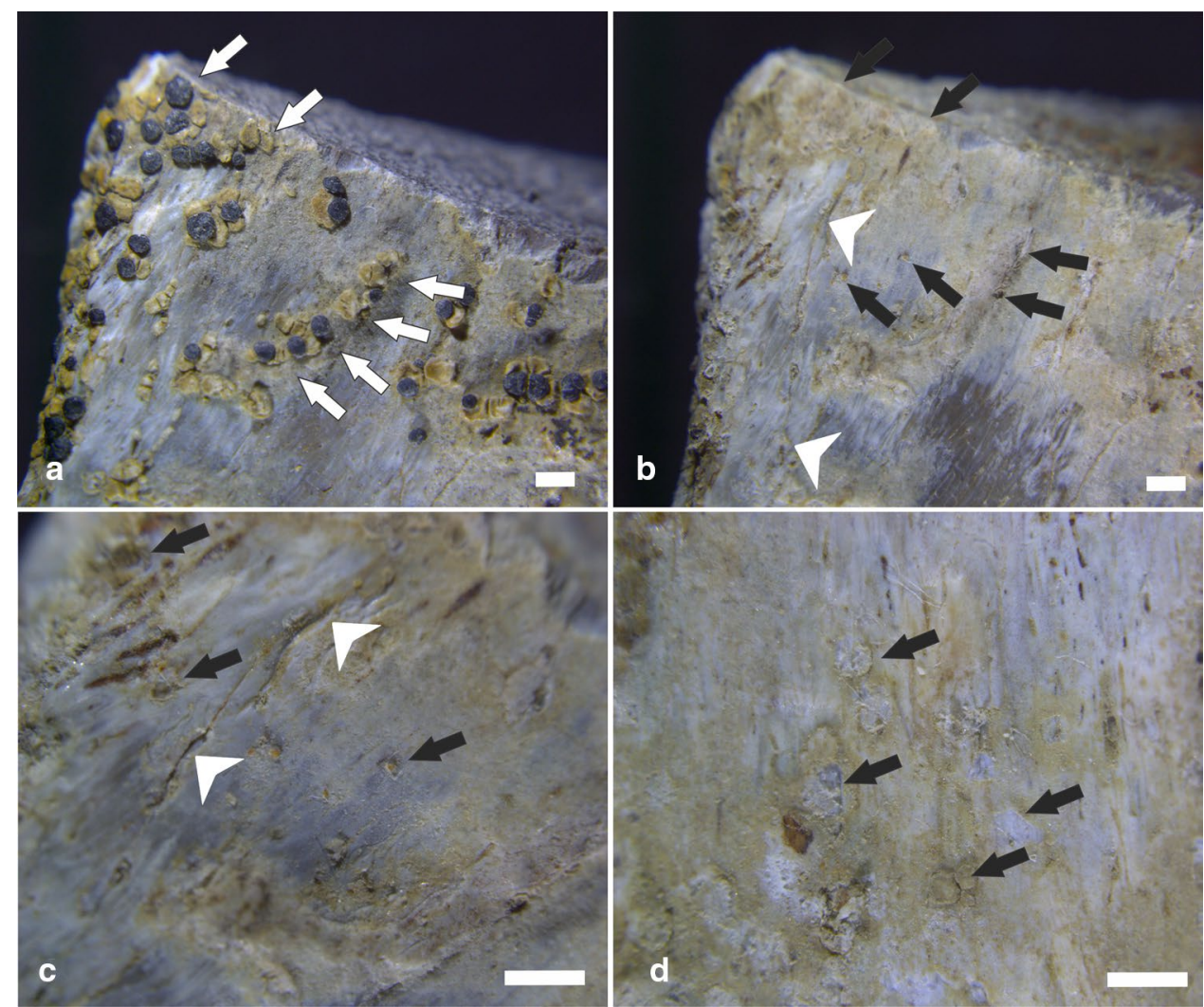

Apothecia of $L$. andersonii are scattered over the entire surface of the samples growing into small holes, accommodated in the spaces of the trabecular bone and also taking advantage of the cracks. On the contrary, A. holocarpa is not so widely spread and only appears in the surface of $08-\mathrm{XI}-$ 30-3/12B, with a lower density than L. andersonii.

\section{Internal taphonomic damage}

The examination of MLP 12-I-20-34 permits recognition of different lichenologic structures. Numerous apothecia of different sizes belonging to L. andersonii (Fig. 2a) are aligned on the surface producing bioerosive damage. The damage occasioned by the lichens was corroborated after cleaning. Traces (Fig. 2b-d) coincident with the apothecia and thallus shown in Fig. 2a are evidenced. Fissures (Fig. 2c) and subcircular marks (Fig. 2d) are dispersed on the surface producing a subtle decoloration and a shallow negative relief.

The internal damage attributed to lichens is observed in the cross section (Fig. 3a-c). Lichen remains were identified at $2 \mathrm{~mm}$ (Fig. 3a, b) and $2.5 \mathrm{~mm}$ depths (Fig. 3a, c). The areas attacked by lichens are shown in the image as rough areas (Fig. 3b, c) in which the carbon peaks are higher than those in the areas of the bone that are not colonized. In contrast, we could not detect any structure or element consistent with lichenologic activity in the EDAX analyses on central areas of the fossil (Fig. 3d-g). The results obtained at
$2.7 \mathrm{~mm}$ depth (Fig. 3d-f) show elements compatible with the fossil bone (phosphorus, calcium, and oxygen) and the surrounding authigenic minerals such as pyrite (iron, silicium, and others in minor proportions). Finally, the most central portion of the fossil, at $5 \mathrm{~mm}$ depth (Fig. 3e-g), shows elements consistent with the fossilized bone.

Hyphae extend below the surface in MLP 12-1-20-34 (Fig. 4), and connect the apothecia that extend to a depth of just a few micrometers below the surface (Fig. 4b). Apothecia rise to the surface, generating thin and small cracks through which hyphae also emerge (Fig. 4c). The superficial pattern of the cracks matches with the hyphae beneath the surface (Fig. 4d). In a cross section, hyphae penetrate up to $2 \mathrm{~mm}$ below the surface of the periosteal bone, reaching/ without reaching the underlying trabecular bone (Fig. 4e).

Another example is given by MLP 08 XI 30 3-12B, the only specimen colonized by $A$. holocarpa from the sample examined here (Fig. 5a). A detail of one the apothecia (Fig. 5b) enables determination of the hyphae extended into the fossil about $1 \mathrm{~mm}$ depth and a second apothecium, under which a cavity probably generated by the lichen growth (Fig. 5c). Small pits regularly distributed on the fossil surface reveal the detachment of apothecia (Fig. 5d, e). A closeup of these surficial circular marks evidences the presence of hyphae related to these pits (Fig. 5e).

In specimen 08-XI-30-3/12A (Fig. 6), an apothecia of L. andersonii grows on the surface and penetrates inward 

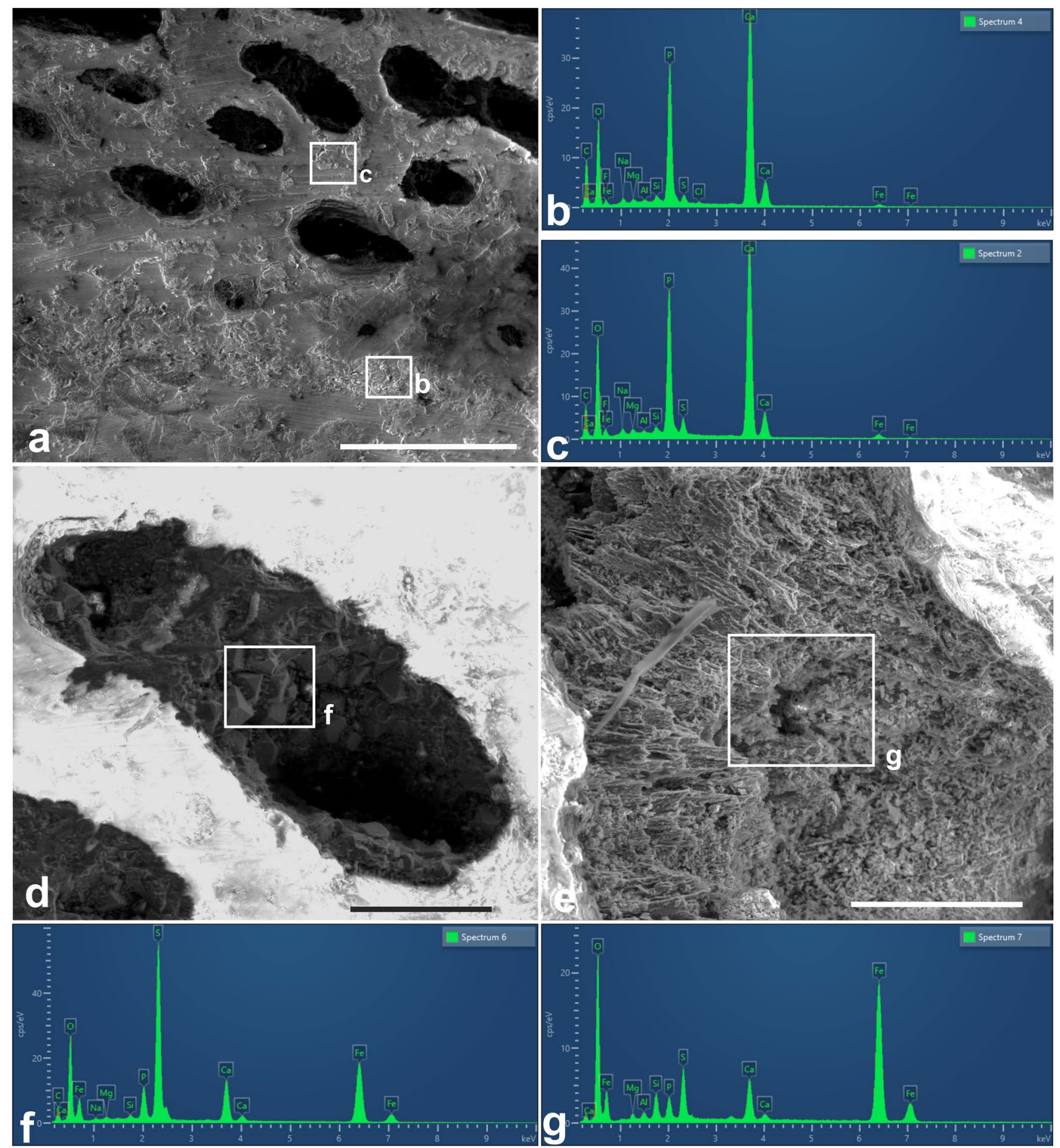

Fig. 3 EDAX analysis of fossil specimen MLP 12-1-20-34. a Cross section of the material showing the places (b and c) selected for EDAX analyses. Scale bar: $500 \mu \mathrm{m}$. b EDAX spectrum of the analysis made at $2 \mathrm{~mm}$ surface depth. c EDAX spectrum of the analysis made at $2.5 \mathrm{~mm}$ surface depth. d Cross section showing cubic pyrite at $2.7 \mathrm{~mm}$ depth. Scale bar: $100 \mu \mathrm{m}$. e Close-up of the innermost area of the bone. Scale bar: $200 \mu \mathrm{m}$. f EDAX profile of the trabeculae shown in (d). $\mathbf{g}$ Elements profile of the EDAX analysis at $5 \mathrm{~mm}$ depth shown in (e), in the composition it is possible to recognize the predominance of the elements " $\mathrm{S}$ " and "Fe" that make up pyrite, in addition to the elements of bone apatite 


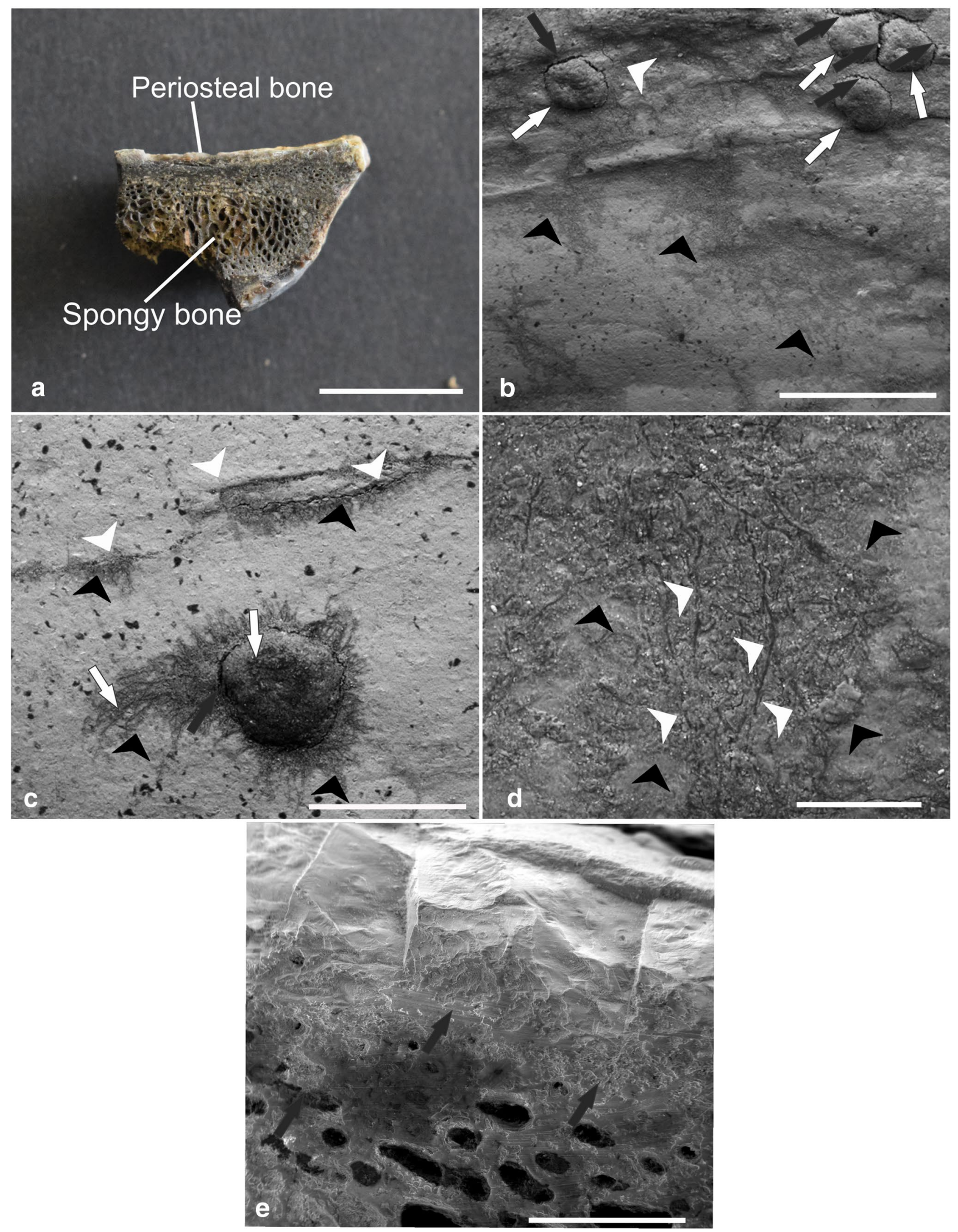


४Fig. 4 Fossil specimen MLP 12-I-20-34. a Cross section showing the periosteal compact bone and the spongy bone. Scale bar: $1 \mathrm{~cm} . \mathbf{b}$ Surface of the fossil under backscattered electron detection in black showing small fissures surrounding the apothecia of $L$. andersonii. Scale bar: $1 \mathrm{~mm}$. c A network of hyphae emerging from around the apothecium. Scale bar: $500 \mu \mathrm{m}$. d The cracks correspond to the growth direction of the hyphae. Scale bar: $100 \mu \mathrm{m}$. e SEM image of the cross section, hyphae network growing into the fossil bone. Scale bar: $1 \mathrm{~mm}$. White arrow: apothecia; black arrows: apothecium pit; white arrowheads: cracks; black arrowhead: hyphae

constituting tangles of compact hyphae in the intertrabecular spaces (Fig. 6b). Two areas of the bones, selected at different depths, were compared. In the first case, detail of a hypha is observed within the white frame (Fig. 6c). The carbon peak observed at the left of the spectrum obtained at $0.5 \mathrm{~mm}$ depth (Fig. 6e) verifies the presence of hyphae, whereas the other elements correspond with the fossil bone composition (phosphorus, calcium, and oxygen) and the surrounding sediment (e.g., iron, silicon). On the contrary, the central sector of the bone, at $4 \mathrm{~mm}$ depth (Fig. 6d) presents an EDAX spectrum (Fig. 6f) only with elements consistent with the fossilized bone (phosphorus, calcium, and oxygen).

\section{Discussion and conclusions}

Our results contribute to knowledge on the bioerosive damage produced by lichens on fossil bones and their taphonomic history. Previous reports of bioerosion by lichens refer exclusively to surficial traces, but we went one step further and (traced) searched the hyphae within the bone, determining the maximum depth to which they extend. In this way, we provide new elements of analysis that allow us to distinguish the traces produced by roots (see also Mikuláš, 1999a, b, 2001; Francischini et al. 2020) from those generated by lichens.

Firstly, we successfully tested the use of electron microscopy techniques (EDAX analysis, SEM magnification, and backscatter electron detection) to recognize the lichen content in a fossil bone. Consequently, we were able to distinguish the lichenologic damage from other kinds of weathering.

There is a correspondence between the highest calcium peaks and the sectors where hyphae were found. The organic acids generated by the lichens could be affecting the calcium of the fossil bones, possibly forming compounds such as calcium oxalate, which would increase the concentration of calcium around the hyphae of the lichen. Calcium oxalate is a compound that many lichens have been observed to form as a secondary metabolite during rock weathering (De los Ríos et al. 2005; Frank-Kamenetskaya et al. 2019). Singh et al. (2013) observed the presence of calcium oxalates in traces on calcareous rocks where a community with
L. andersonii, among other lichens, lived. This allows us to assume that $L$. andersonii could be an active producer of calcium oxalates.

Some differences between the analyzed fossil specimens were observed. L. andersonii was more frequently found (MLP 08 XI 30 3-12 A, MLP 08 XI 30 3-12 B, MLP 12-120-34) than A. holocarp (only present in MLP 08 XI 30 3-12 B). Both species face the same ecological constraints and their thalli cannot continue to grow into the bone when the light supply is insufficient. In the first millimeters towards the center of the bone, the hyphae grow without difficulties, reaching a maximum of $2.5 \mathrm{~mm}$ depth. Going deeper, where lichen hyphae are not observed, we found crystals of sulfur accumulated in the bone trabeculae. The sulfur associated with fossil bones crystallizes as pyrite under anoxic or suboxic conditions (Canfield 1991; Pfretzschner 2001), creating a hostile environment for aerobic organisms. In other cases, when sulfur appears as crystals of cubic pyrite, it has been attributed to the bacterial activity during the early stages of the decay processes (for example Talevi and Brezina 2019). Besides, the presence of sulfur generates acid in the substrate, and is toxic for most lichens at high concentrations. However, some species are tolerant to these substrate conditions and favor them owing to the low competition for space (Purvis and Halls 1996). In the cases examined here, hyphae and pyrite crystals do not share space, suggesting that $L$. andersonii would be intolerant to this substrate. Fossils with higher sulfur concentration could not be colonized by lichens due to its toxicity to many species.

Although the difference in the substrate provided by spongy and compact bone could not be evaluated properly with regards to lichen preferences, some parameters can be confidently established. Lichens easily grow, taking advantage of preexisting cracks and holes in rocks and bones. In the latter, diagenetic fractures and medullary cavities or aerial spaces in the bone are used for anchoring the thallus. Spongy bone provides an adequate rough surface, but is only accessible when the fossil is broken. Due to its photosynthetic condition, most of the thallus will be restricted to a few millimeters above the surface where the sunlight can be used more efficiently.

In all these cases, the lichens, invariably classified here as euendolithics, caused different erosive damage. The fruiting bodies, apothecia, produce holes of different sizes $(0.5-50 \mu \mathrm{m})$ and variable depths, associated with microfissures affecting the periosteal bone around them. These thin and microscopic fissures are also related to the hyphae growth in the bone surface. We could also establish that the shallower, rounded, and subrounded marks observed in the surface of the fossils correspond to the negative relief left by apothecia when falling. Consequently, we have expanded the usual substratum in which euendolithic lichens grow, including calcium phosphate substrates such as the fossilized 

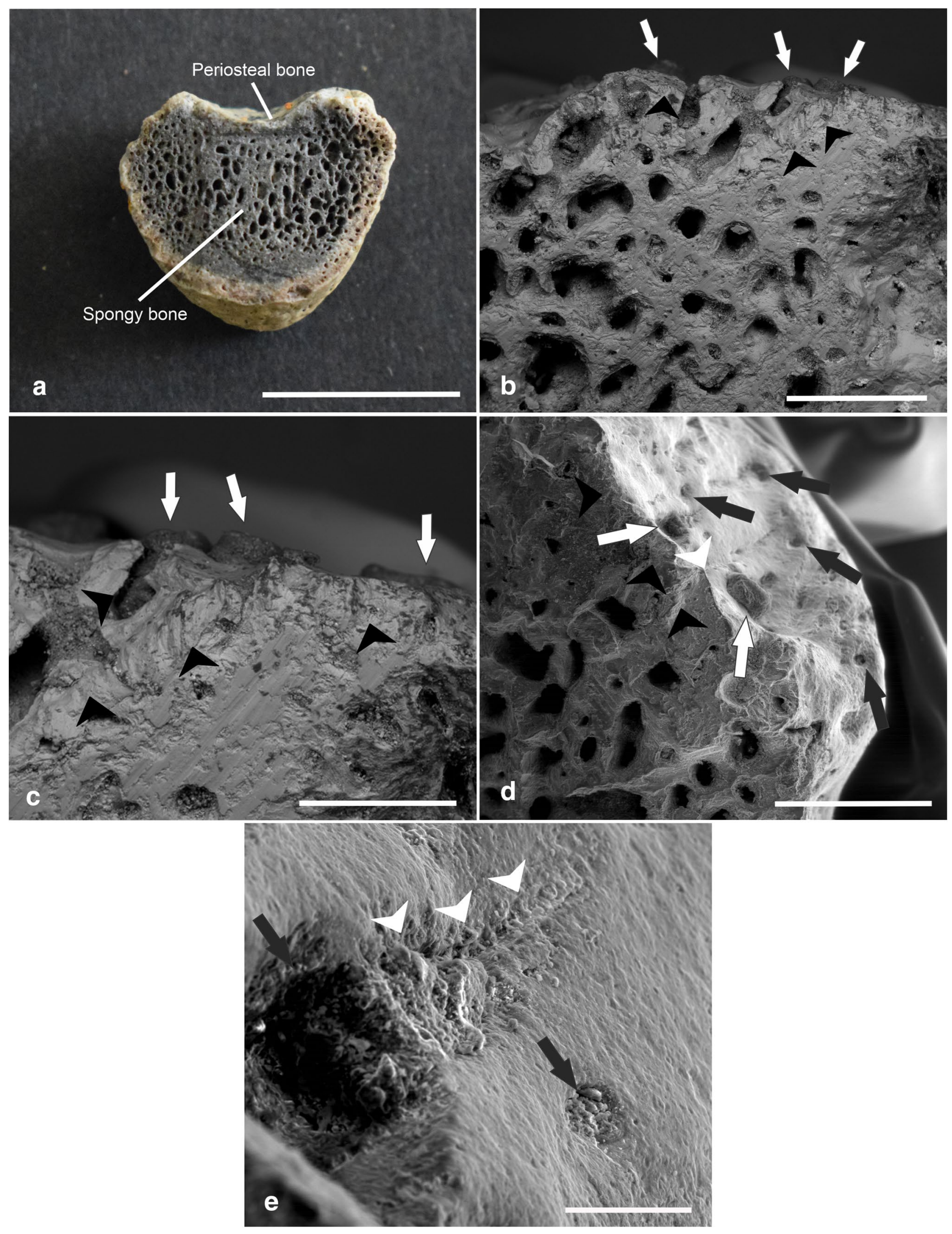
4Fig. 5 Fossil specimen MLP 08 XI 30 3-12 B. a Cross section showing the periosteal compact bone and the spongy bone. Scale bar: $1 \mathrm{~cm}$. b Cross section under backscatter electron detection mode, the inset shows the location of apothecia and associated hyphae of A. holocarpa. Scale bar: $1 \mathrm{~mm}$. c Detail of the apothecium indicated in (b), the hyphae growing into the fossil and an empty perforation previously occupied by an apothecium. Scale bar: $500 \mu \mathrm{m}$. d Surface under SEM showing apothecia and perforations (white arrows). Scale bar: $100 \mu \mathrm{m}$. e Fracture associated with apothecium growth. Other perforations are also indicated. Scale bar: $100 \mu \mathrm{m}$. White arrow: apothecia; black arrows: apothecium pit; white arrowheads: cracks; black arrowhead: hyphae

bones analyzed here. The presence of secondary acid metabolites reported in both species studied here (Øvstedal and Smith 2001; Olech 2004; Arup 2009; Ruprecht et al. 2010) would actively help penetration into the bone. The biological activity and lichen growth produce thin sinuous fissures only visible with high magnification, different from the linear cracks produced by physical weathering (e.g., frost wedging, erosion by wind or snow, transportation).

Endolithic lichens, previously found in other penguin bones and shark teeth, leave pits and, in some cases, whitish traces on the fossil surface. These lichen traces, named as type 1 in Acosta Hospitaleche et al. (2011) were recognized in early Miocene fossils from the Gaiman Formation (Patagonia, Argentina). These individual traces, made by Sarcogyne regularis Körb. 1855, Verrucaria sp., and Buellia aff. punctiformis (DC.) A. Massal. 1852, leave grooves lighter than surrounding bone or enameloid surfaces and with an unbranched and intercrossed random pattern with a constant hyporelief. We did not find these corrosive traces in the materials examined here, where hyphae of $L$. andersonii and A. holocarpa were mostly recognized inside the bone rather than on the surface. Type 2 lichen traces (Acosta Hospitaleche et al. 2011) were isolated, small, subspherical, and slightly concave pits without associated whitish traces. These structures, previously found in Antarctic teeth, are equivalent to the holes belonging to the apothecia described above.

As stated before, all these marks are useful tools for reconstructing the chronology of the taphonomic events in paleontological and archaeological contexts. As lichens need light to grow, the finding of any bioerosive structure of lichenology origin imply that the fossil was exhumed during the time that the lichen colonized the bone. The small fissures and/or the whitish traces related to the lichen activity crossover previous diagenetic cracks and remodel the edges of the fractures. Besides, as we have demonstrated, the extension of the hyphae in the interior of the bone is constrained by sunlight, therefore, the presence of lichen in deeper areas of spongy bone is only possible when the material is fractured. We also recognized the damage produced by lichens when the thalli and apothecia were completely degraded, for example after a new burial event.

Lichen traces can also alter the morphology of preexistent traces such as predation marks, fractures of fresh or mineralized bones (Cione et al. 2010; Acosta Hospitaleche et al. 2012), and wear marks on anthropological pieces of rock (Magnin et al. 2017). Therefore, the proper recognition of lichen traces minimizes error margins during the examination of fossils or archaeological pieces, and contributes to the reconstruction of the taphonomic history of the bones.

Furthermore, although we observed biodeterioration by lichens on penguin bones as a modern process, it could have occurred in the same way in the past. The climatic conditions, substrate, and taphonomic process involving lichens could have been acting this way since Eocene times. Recognition of these traces is still a challenge. Unfortunately, we could not find an equivalent study to compare our results. Modern lichens have been previously recognized on fossil surfaces but never analyzed in a broader taphonomic context such as this. Our results, including analyses of the innermost part of the bones, are a first step in this direction. 


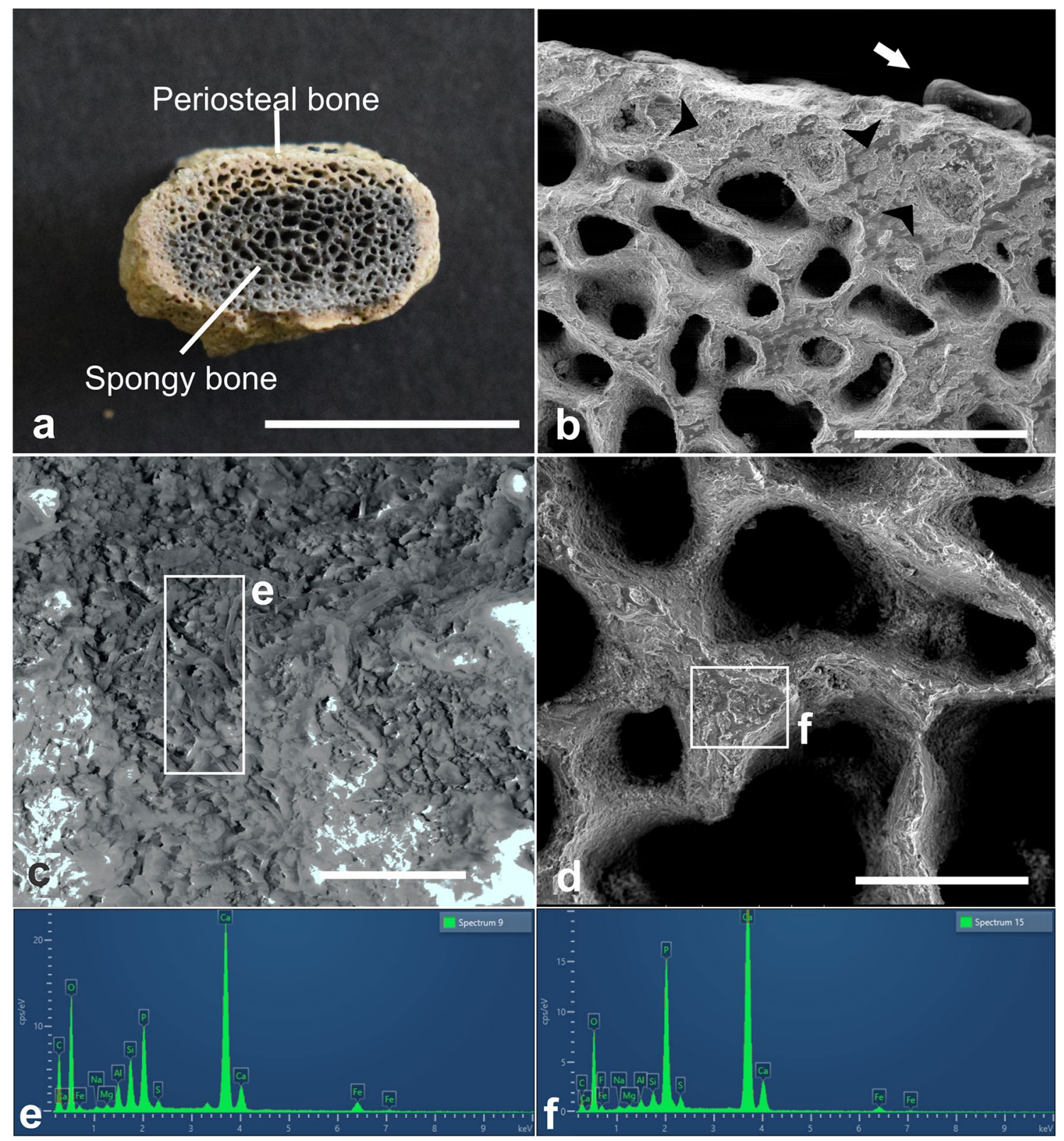

Fig. 6 Fossil specimen MLP 08 XI 30 3-12 A. a Cross section showing the periosteal compact bone and the spongy bone. Scale bar: $1 \mathrm{~cm}$. b Cross section showing an apothecium on the bone surface and the hyphae extending into the bone. Scale bar: $1 \mathrm{~mm}$. c Area of the section with visible hyphae (rectangle indicated with a) where EDAX analysis shown in (e) was undertaken. Scale bar: $50 \mu \mathrm{m}$. d
Area of the section (square indicated with b), where the EDAX analysis shown in (f) was undertaken. Scale bar: $500 \mu \mathrm{m}$. e Spectrum of EDAX analysis corresponding to the area indicated in (c). $\mathbf{f}$ Spectrum of EDAX analysis corresponding to the area indicated in (d). White arrow: apothecia, black arrowhead: hyphae 
Acknowledgements This contribution honors Vilma Rosato for helping us in our first steps through the study of endolithic lichens into paleontological contexts. We thank Marcelo Reguero for the access to the materials, and Juan José Moly for the transversal sections. C.A.H. was invited to the field by the National Antarctic Directorate and the Argentine Antarctic Institute. The Argentine Air Force provided logistical support. C.A.H. is particularly grateful to Oceanwide Expeditions, Vlissingen (NL) for financial support. We thank the reviewers Dr. Radek Mikulas and Dr. Leandro Pérez for their useful comments.

Author contributions R.G., C.A.H., and G.M. conceived and designed research. R.G. prepared the samples. R.G., C.A.H., and G.M. analyzed data and interpreted the results. All authors prepared the images, wrote the manuscript, and approved the manuscript.

Funding This work was partially supported by grants from ANPCyT, PICT 2017-0043 (GJM) and UNLP N955 (CAH).

Data availability Materials reviewed in this work are housed in the collection of the División Paleontología Vertebrados (DPV) of the Museo de La Plata (MLP), La Plata (Argentina): MLP 08-XI-30-3/12A, MLP 08-XI-302-3/12B, and MLP 12-I-20-34.

Code availability Not applicable.

\section{Declarations}

Conflict of interest The authors declare that they have no conflicts of interest.

Ethical approval The senior curator of the División Paleontología Vertebrados (Museo de La Plata), La Plata (Argentina) allowed access to the fossil penguin bones analyzed in the present contribution, and the permission for publication of the results, all according to Argentinian laws and requirements, in accordance with the Antarctic Treaty.

Consent to participate All authors declare having consented to participation in this study.

Consent for publication All authors declare their consent to the publication of this manuscript.

\section{References}

Acosta Hospitaleche C, Márquez G, Pérez LM, Rosato V, Cione AL (2011) Lichen bioerosion on fossil vertebrates from the Cenozoic of Patagonia and Antarctica. Ichnos 18:1-8

Acosta Hospitaleche CA, Pérez LM, Acosta W, Reguero M (2012) A traumatic fracture in a giant Eocene penguin from Antarctica. Antarct Sci 24:619-624

Adamo P, Violante P (1991) Weathering of volcanic rocks from Mt. Vesuvius associated with the lichen Stereocaulon vesuvianum. Pedobiologia 35:209-217

Arup U (2009) The Caloplaca holocarpa group in the Nordic countries, except Iceland. Lichenologist 41:111-130

Ascaso C, Wierzchos J, de los Ríos A (1995) Cytological investigations of lithobiontic microorganisms in granitic rocks. Bot Acta 108:474-481

Ascaso C, Wierzchos J, Souza-Egipsy V, De los Rios A, Delgado-Rodriguez $\mathbf{J}$ (2002) In situ evaluation of the biodeteriorating action of microorganisms and the effects of biocides on carbonate rock of the Jeronimos Monastery (Lisbon). Int Biodeterior Biodegrad 49:1-12

Bachmann E (1890) Die Beziehungen der Kalkflechten zu ihrem Substrat. Ber Dtsch Bot Ges 8:141-145

Bachmann E (1892) Der Thallus der Kalkflechten. Ber Dtsch Bot Ges 8:141-145

Bachmann E (1913) Der Thallus der Kalkflechten II. Ber Dtsch Bot Ges 31:3-12

Bachmann E (1919) Der Thallus der Kalkflechten III. Nova Acta Leopol 100:1-80

Barker WW, Banfield JF (1996) Biologically versus inorganically mediated weathering reactions: relationship between minerals and extracellular microbial polymers in lithobiontic communities. Chem Geol 132:55-69

Behrensmeyer AK (1978) Taphonomic and ecologic information from bone weathering. Paleobiology 4:150-162

Bjelland T, Saebo L, Thorseth IH (2002) The occurrence of biomineralization products in four lichen species growing on sandstone in western Norway. Lichenologist 34:229-440

Bjelland T, Grube M, Hoem S, Jorgensen SL, Daae FL, Thorseth IH, Øvreås L (2011) Microbial metacommunities in the lichenerock habitat. Environ Microbiol Rep 3:434-442

Canfield DE (1991) Pyrite formation and fossil preservation. Taphonomy: releasing the data locked in the fossil record. Geobiology 9:337-387

Cione AL, Acosta Hospitaleche C, Pérez LM, Laza JH, César I (2010) Trace fossils on penguin bones from the Miocene of Chubut, Southern Argentina. Alcheringa 34:433-454

De los Ríos A, Ascaso C (2005) Contributions of in situ microscopy to the current understanding of stone biodeterioration. Int Microbiol $8: 181-188$

De los Ríos A, Wierzchos J, Sancho LG, Sancho TG, Ascaso C (2005) Ecology of endolithic lichens colonizing granite in continental Antarctica. Lichenologist 37:383-395

de Los Ríos A, Cámara B, Del Cura MAG, Rico VJ, Galván V, Ascaso C (2009) Deteriorating effects of lichen and microbial colonization of carbonate building rocks in the Romanesque churches of Segovia (Spain). Sci Total Environ 407:1123-1134

De los Ríos A, Perez-Ortega S, Wierzchos J, Ascaso C (2012) Differential effects of biocide treat-ments on saxicolous communities: case study of the Segovia cathedral cloister (Spain). Int Biodeterior Biodegrad 67:64-72

Doppelbaur HW (1959) Studien zur Anatomie und Entwicklungsgeschichte einiger endolithischen pyrenocarpen Flechten. Planta 53:246-292

Edwards HGM, Farwell DW, Seaward MRD (1991) Raman spectra of oxalates in lichen encrustations on Renaissance frescoes. Spectrochim Acta 47:1531-1539

Edwards HGM, Farwell DW, Jenkins R, Seaward MRD (1992) Vibrational Raman spectroscopic studies of calcium oxalate monohydrate and dihydrate in lichen encrustations and Renaissance frescoes. J Raman Spectrosc 23:185-189

Edwards HGM, Farwell DW, Seaward MRD (1994a) FT-Raman spectroscopic studies of lichen encrustations on Renaissance frescoes. Deutsche Gesellschaft Für Zerstörungsfreie Prüfung E 45:743-752

Edwards HGM, Edwards KAE, Farwell DW, Lewis IR, Seaward MRD (1994b) An approach to stone and fresco lichen biodeterioration through Fourier transform Raman microscopic investigation of thallus-substratum encrustations. J Raman Spectrosc 25:99-103

Francischini H, Lucas SG, Dentzien-Dias P, Schultz CL (2020) Recent root damages of fossilized vertebrate remains from New Mexico, USA. In: Martínez S, Rojas A, Cabrera F (eds) Actualistic taphonomy in South America. Springer, Cham, pp 139-150 
Frank-Kamenetskaya OV, Ivanyuk GY, Zelenskaya MS, Izatulina AR, Kalashnikov AO, Vlasov DY, Polyanskaya EI (2019) Calcium oxalates in lichens on surface of apatite-nepheline ore (Kola Peninsula, Russia). Minerals 9:656

Friedmann EI (1982) Endolithic microorganisms in the Antarctic cold desert. Science 215:1045-1053

Friedmann EI, Ocampo-Friedmann R (1984) Endolithic microorganisms in extreme dry environments: analysis of a lithobiontic microbial habitat. In: Klug MJ, Reddy CA (eds) Current perspectives in microbial ecology. proceedings of the Third International Symposium on Microbial Ecology. American Society for Microbiology, Washington D.C., pp 177-185

Fry EJ (1922) Some types of endolithic limestone lichens. Ann Bot 36:541-562

Fry EJ (1927) The mechanical action of crustaceous lichens on substrata of shale, schist, gneiss, limestone, and obsidian. Ann Bot 41:437-460

Galván Josa V, Fracchia D, Castellano G, Crespo E, Kang A, Bonetto R (2013) Backscattered electron images, X-ray maps and Monte Carlo simulations applied to the study of plagioclase composition in volcanic rocks. Spectrochim Acta Part B At Spectrosc 8:50-58

García R, Márquez G, Hospitaleche CA (2020) Richness of lichens growing on Eocene fossil penguin remains from Antarctica. Polar Biol 43:2011-2019

Gazzano C, Favero-Longo SE, Matteucci E, Roccardi A, Piervittori R (2009) Index of lichen potential biodeteriogenic activity (LPBA): a tentative tool to evaluate the lichen impact on stonework. Int Biodeterior Biodegrad 63:836-843

Golubic S, Friedmann I, Schneider J (1981) The lithobiontic ecological niche, with special reference to microorganisms. J Sediment Petrol 51:475-478

Gouiric-Cavalli S, Rasia LL, Márquez GJ, Rosato V, Scasso RA, Reguero M (2018) First pachycormiform (Actinopterygii, Pachycormiformes) remains from the late jurassic of the Antarctic Peninsula and remarks on bone alteration by recent bioeroders. J Vertebr Paleontol 38:e1524384

Jones D, Wilson MJ, Tait JM (1980) Weathering of a basalt by Pertusaria corellina. Lichenologist 12:277-289

Kappen L, Friedmann EI, Garty J (1981) Ecophysiology of lichens in the dry valleys of Southern Victoria Land, Antarctica. I. Microclimate and the cryptoendolithic lichen habitat. Flora 171:216-235

Khomutovska N, de Los RA, Jasser I (2021) Diversity and colonization strategies of endolithic cyanobacteria in the cold mountain desert of Pamir. Microorganisms 9:6

Krumbein WE (1969) Über den Einfluss der Microflora auf die exogene Dynamik (Verwitterung und Krustenbildung). Geol Rundsch 58:333-363

Lange OL, Schulze ED, Koch W (1970) Experimentell-ökologische Untersuchungen an Flechten der Negev-Wüste. III. CO2-Gaswechsel und Wasserhaushalt von Krusten- und Blattflechten am natürlichen Standort während der sommerlichen Trockenperiode. Flora 159:525-538

Magnin L, Lynch V, García R (2017) Avances en el estudio de biodeterioro asociado a presencia de líquenes en materiales arqueológicos líticos. La Primavera (Santa Cruz, Argentina). Bol Soc Argent 52:409-422

Matthes U, Turner SJ, Larson DW (2001) Light attenuation by limestone rock and its constraint on the depth distribution of endolithic algae and cyanobacteria. Int J Plant Sci 162:263-270

Mikuláš R (1999a) Notes to the concept of plant trace fossils related to plant-generated sedimentary structures. Bull Czech Geol Surv 74:39-42

Mikuláš R (1999b) Fossil corrosive root traces on rock surfaces and bioclasts (Bohemian Cretaceous Basin, Czech Republic). Bull Czech Geol Surv 74:289-292
Mikuláš R (2001) Modern and fossil traces in terrestrial lithic substrates. Ichnos 8:177-184

Montes M, Nozal F, Santillana SN, Marenssi S, Olivero E (2013) Mapa Geológico de Isla Marambio (Seymour), Antártida; escala 1: 20.000. Serie Cartográfica Geocientífica Antártica Geológico y Minero de España, 1a edición. Buenos Aires, Argentina: Instituto Antártico Argentino

Nimis PL, Pinna D, Salvadori O (1992) Licheni e Conservazione dei Monumenti. Editrice Bologna, Bologna

Olech M (2004) Lichens of King George Island, Antarctica. Institute of Botany of the Jagiellonian University, Kraków

Øvstedal DO, Smith RI (2001) Lichens of Antarctica and South Georgia: a guide to their identification and ecology. Studies in Polar Research, Cambridge University Press, Cambridge

Pfretzschner HU (2001) Pyrite in fossil bone. N Jb Geol Palaont Abh 220:1-23

Piervittori R, Salvadori O, Laccisaglia A (1994) Literature on lichens and biodeterioration of stonework I. Lichenologist 26:171-192

Piervittori R, Salvadori O, Laccisaglia A (1996) Literature on lichens and biodeterioration of stonework II. Lichenologist 28:471-483

Piervittori R, Salvadori O, Isocrono D (1998) Literature on lichens and biodeterioration of stonework III. Lichenologist 30:263-277

Purvis OW, Halls C (1996) A review of lichens in metal-enriched environments. Lichenologist 28:571-601

Ruprecht U, Lumbsch HT, Brunauer G, Green TG, Türk R (2010) Diversity of Lecidea (Lecideaceae, Ascomycota) species revealed by molecular data and morphological characters. Antarct Sci 22:727-741

Seaward MRD (1997) Major impacts made by lichens in biodeterioration processes. Int Biodeterior Biodegrad 40:269-273

Seaward MRD (2015) Lichens as agents of biodeterioration. In: Upreti D, Divakar P, Shukla V, Bajpai R (eds) Recent advances in lichenology. Springer, New Delhi, pp 189-211

Seaward MRD, Giacobini C (1988) Oxalate encrustation by the lichen Dirina massiliensis forma sorediata and its role in the deterioration of works of art. In: St.Clair LL, Seaward MRD (eds) Le Pellicole ad Ossalati: Origini e Significato nelle Conversazione della Opere d'Arte. Centro CNR, Milano, pp 115-219

Singh S, Nayaka S, Upreti D (2013) Contribution to the lichen flora of Schirmacher Oasis and Larsemann Hills, Antarctica. In: Tripathy SC, Mishra RK, Mohan R, Khare N (eds) Studies in biological sciences and human physiology. Three decades of Indian scientific activities in Antarctica. National Centre for Antarctic and Ocean Research, Vasco-da-Gama, Goa, pp 135-155

Sterflinger K, Krumbein WE (1997) Dematiaceous fungi as a major agent for biopitting on Mediterranean marbles and limestones. Geomicrobiol J 14:219-230

Syers JK, Iskandar IK (1973) Pedogenic significance of lichens. In: Ahmadjian V, Hale ME (eds) The lichens. Academic Press, New York, pp 225-248

Talevi M, Brezina S (2019) Bioerosion structures in a late Cretaceous mosasaur from Antarctica. Facies 65:5

Tretiach M, Geletti A (1997) CO2 exchange of the endolithic lichen Verrucaria baldensis from karst habitats in northern Italy. Oecologia 111:515-522

Wessels D, Kappen L (1994) Photosynthetic performance of rockcolonising lichens in the Mountain Zebra National Park, South Africa. Koedoe 36:27-48

Publisher's Note Springer Nature remains neutral with regard to jurisdictional claims in published maps and institutional affiliations. 